\title{
Econometric Analysis of the Factors that Affect Adoption of Conservation Farming Practices by Smallholder Farmers in Zambia
}

\author{
John Ng'ombe ${ }^{1}$, Thomson Kalinda ${ }^{1}$, Gelson Tembo ${ }^{1} \&$ Elias Kuntashula ${ }^{1}$ \\ ${ }^{1}$ Department of Agricultural Economics \& Extension, University of Zambia, Lusaka, Zambia \\ Correspondence: Thomson Kalinda, Department of Agricultural Economics and Extension, University of Zambia, \\ Lusaka, Zambia. Tel: 260-9-6645-4366. E-mail: thomsonkalinda@gmail.com
}

Received: May 6, $2014 \quad$ Accepted: May 26, 201x $\quad$ Online Published: July 31, 204
doi:10.5539/jsd.v7n4p124
URL: http://dx.doi.org/10.5539/jsd.v7n4p124

\begin{abstract}
Despite the efforts to promote adoption of conservation farming (CF) by public and private organizations, the adoption rate among Zambian smallholder farm households has been low. This study used nationally representative data to identify the factors that affect adoption of CF by smallholder farm households in Zambia. Propensity Score Matching (PSM) was employed to help match the adopters and non-adopters of CF based on the distribution of their similar observable characteristics upon which a separate logistic model was applied. The logistic regression analysis showed that age of the household head; access to loans; labour availability; in-kind income and location of the households in agro-ecological regions (AER) I and II significantly increases the odds of adoption of CF. Based on these findings, it is recommended that promotion of adoption of CF practices should be directed towards smallholder farm households in AER I and II and those in remote areas which are less accessible by roads. This could be complemented by improving the road infrastructure so that smallholder farmers in such areas would not only have access to agricultural loans but also be in contact with relevant extension organizations that promote $\mathrm{CF}$.
\end{abstract}

Keywords: adoption, conservation farming, smallholder farmers, logistic model, matched sample, Zambia

\section{Introduction and Background}

Soil fertility depletion is one form of land degradation problems that has constrained the growth of the agricultural sector and its productivity in most developing countries. In an effort to reduce poverty levels and food insecurity resulting from such agricultural problems, many African governments have taken ardent interest in promoting conservation farming (CF) practices (Nyangena \& Kohlin, 2008; Nyanga, 2012). CF is arguably considered the strategy suitable to maintain environmental sustainability and result into welfare gains in agriculture (Kassie et al., 2008). Giller et al., (2009) observed that CF is claimed to be the panacea to the declining agricultural productivity and soil degradation problems.

Typically, CF involves the practice of dry-season land preparation, minimum tillage, crop residue retention, and nitrogen-fixing crop rotations (Haggblade \& Tembo, 2003; FAO, 2006; Hobbs, 2007; CFU, 2007; Simpson \& Weamert, 2007). CF practices in Zambia date back to the late 1980s and early 1990s (Haggblade \& Tembo, 2003). In the late 1990s and early 2000s, CF practices attracted the attention of a number of donor-financed non-governmental organizations (NGOs) such as the Co-operative League of the United States of America (CLUSA). CLUSA required its farmers to plant in CF basins as a pre-requisite for receiving input credit. Dunavant Zambia Limited increased its commitment to $\mathrm{CF}$ in its farmer training and support programmes (Haggblade \& Tembo, 2003). The major objective of these activities was to increase knowledge and adoption of CF practices by smallholder farmers in Zambia.

These efforts to promote CF captured interest from many stakeholders. For example, the Government of the Republic of Zambia (GRZ) has since the mid-1990s affirmed that it would promote CF practices to the farming population (Haggblade \& Tembo, 2003). Other major stakeholder institutions joined in the efforts to promote CF among smallholder farmers. These were the Conservation Farming Unit (CFU) under the Zambia National Farmers Union (ZNFU); the Department of Field Services in the Ministry of Agriculture and Co-operatives (MACO); the Soil Conservation and Agro-forestry Extension Project (SCAFE) and the Golden Valley Agricultural Trust (GART). These cooperating institutions ensured that smallholder farmers had access to extension services that incorporated CF practices. By mid-1990s, CF practices were known by a number of 
Zambian smallholder farmers (Haggblade \& Tembo, 2003). In 1998, MACO formally embraced CF as an official policy in the agricultural sector (CFU, 2007).

Despite continued efforts to promote adoption of $\mathrm{CF}$ in most developing countries, the adoption rate has been low (Fowler \& Rockstrom, 2001; Derpsch, 2003; Hobbs, 2007). For example, it is estimated that about 10 percent of the smallholder farmers adopt some form of CF practices in Zambia (Haggblade \& Tembo, 2003; CFU, 2005). Arslan et $a l$, (2013) also document high levels of dis-adoption (around 95\%) of these practices in the whole country, something that raises the question of widespread suitability of these CF practices. This scanty empirical evidence on the low levels of adoption of $\mathrm{CF}$ and the reasons behind this motivated the need to investigate the factors that affect its adoption.

Therefore, the main objective of this study was to identify the factors that affect adoption of CF by smallholder farm households in Zambia. Past studies on factors that affect adoption of CF practices were often not based on adopters and non-adopters with statistically similar distribution of their observable characteristics. Therefore, it is possible their results might be biased and inconsistent (Heckman et al, 1998). Filling this methodological gap could generate important knowledge for identifying interventions that can effectively accelerate adoption of CF. Thus, the findings of this study could be of interest to several development stakeholders, including relevant Government agencies (research, extension, policy and planning) and Non-Governmental Organizations (NGOs).

\subsection{Review of the Literature}

Several empirical studies have been carried out to investigate the economics and adoption dimensions of CF practices in Zambia and other developing countries (for example, Gebermedhin \& Swinton, 2001; Haggblade \& Tembo, 2003; Chomba, 2004; Kabwe \& Donovan, 2005; Rockström et al., 2009; Chiputwa et al., 2011; Nkegbe et al., 2011; Nyanga et al., 2011; Kassie et al., 2012; Nyanga, 2012). Tembo and Haggblade (2003) and Nyanga et al. (2011) observed that the Agro-Ecological Region (AER) in which the smallholder farm household is located is highly significant in determining adoption of CF practices (Note 1). For example, animal draught ripping and basins are found to be best suited and highly adopted in AER I, an area characterized by sporadic and erratic rainfall patterns. This is mainly because the basins are designed to hold moisture in drought persistent areas and thus are more likely to be adopted in AER I as compared to AER III.

Tembo and Haggblade (2003) found that extension support to the households, cattle ownership and asset holding were also significant in determining adoption of CF practices. These results are consistent with other studies on CF in Zambia (for example, Keyser \& Mwanza, 1996; Chomba, 2004; Kabwe \& Donovan, 2005). The study by Chomba (2004) showed that addressing the conditions that may inhibit financial incentives arising from reduced production costs and accessibility to source of support services positively influences farmers to implement conservation farming and other sets of practices. Chomba (2004) also noted that physical constraints and climatic factors such as droughts associated with the geographical location of households are significant in adoption of CF practices, an observation in agreement with Clay et al. (2002), Ervin \& Ervin (1982), Reardon and Vosti (1997a) and Gebremedhin and Swinton (2003).

Studies on CF from other countries show similar results on factors that affect adoption of CF practices. Kessie $e t$ al. (2012) showed that both socioeconomic and plot characteristics are significant in adoption of CF practices in areas or years where rainfall is erratic in rural Tanzania. These results are consistent with Haggblade and Tembo (2003) for Zambia; Jansen et al. (2006) for Honduras and Kassie et al. $(2008$; 2009) for Ethiopia. Kassie et al. (2012) also reveal that adoption of CF practices is affected by land tenure status of the household. These results are consistent with earlier work on technology adoption (e.g., Arellanes \& Lee, 2003; Gebremedhin \& Swinton, 2003; Tenge et al., 2004; Jansen et al., 2006; Kassie et al., 2009; Nyangena, 2011).

Kassie et al. (2012) attributed the effect of the land tenure status of the household on adoption of CF practices to the fact that the benefits from long term CF practices accrue over time. They note that farmers who own their land will have a higher probability of adopting CF practices in the long term. However, Kassie and Holden (2006) found that this is not true in the short term. In their study on impact of CF practices on productivity in Ethiopian highlands, they found that smallholder farmers are more likely to practice CF on rented plots than on their own, perhaps due to lack of land tenure security.

To shade more light about the significance of land tenure in affecting adoption of CF, Gebermedhin and Swinton (2001) exceptionally pointed out that most other studies employ either a single measure of land tenure status (Ervin \& Ervin, 1982; Feder et al., 1988; Shiferaw \& Holden, 1998) or a single measure of land improvement (Gavian \& Fafchamps, 1996; Pender \& Kerr, 1998; Shiferaw \& Holden, 1998). They further observed that this makes it impossible to link the degree of land tenure security with the longevity of land improvement investment through CF. This may be true because of the time lags between when benefits kick start and when the 
smallholder farmer decides to adopt CF packages. Such time lapses can affect the smallholder farmers' propensity to adopt $\mathrm{CF}$ as observed by Hobbs (2007).

Kassie et al. (2012) also found that household's participation in at least one rural institution or group and extension support from skilled civil servants is significant in adoption of CF practices because of increased chance of interaction and access to quality knowledge among farmers. This result is consistent with other studies (Haggblade \&, Tembo 2003; Kassie et al. 2009; Wollni et al. 2010; Nyangena 2011).Kassie et al. (2012) additionally found that the size of the household, retired staff status and off-farm income are significant in adoption of CF practices. Tembo and Haggblade (2003) and Marenya and Barrett (2007) observed a similar result in Zambia and Kenya respectively. Other factors that are found to be significant in adopting CF practices by Kassie et al. (2012) are government support, AER, plot characteristics, and asset ownership. This finding is consistent with Haggblade and Tembo (2003); Chomba (2004); Kabwe and Donovan (2005), Pender and Gebremedhin (2007) and Nyanga (2012). However, on household size, Clay and Reardon (1994) noted that large sized households, ceteris paribus, may be more likely than small sized households to adopt CF practices of all types. They noted that quality of human capital can also make a huge difference in adopting CF practices in addition to the amount of labor available in the household. This is somehow consistent with the results by Nyanga (2012) in Zambia who observed that the number of CA trainings attended, traditional leadership had a positive influence on adoption of CA but his results might be clouded with possible endogeneity of CA technologies and possible self-selection since they were based on the sample of smallholder farmers under Conservation Agricultural Program (CAP).

Furthermore, Gerbermedhin and Swinton (2001) observed that one of the shortcomings of the existing conservation literature is the assumption that the factors affecting adoption of conservation practices are the same as those that determine the intensity of their use. They further contended that most studies have focused on adoption alone, using logit, probit or linear probability models (for example Feder et al., 1988; Place \& Hazell, 1993; Gavian \& Fafchamps, 1996; Hayes et al., 1997; Shiferaw \& Holden, 1998). In this instance, a study by Gebermedhin and Swinton (2001) was exceptional as it used a double hurdle model to be able to determine the intensity of use once CF is adopted. However, studies by Shiferaw and Holden (1998) and by Gebermedhin and Swinton (2001) did not analyze results based on matched observations between adopters and non-adopters of soil conservation practices. As mentioned before, conclusions based on non-matched observations maybe biased and inconsistent (Heckman et al., 1998).

To improve on any likely shortfalls of previous literature and contested evidence about the factors that affect adoption of CF in Zambia, this study contributes to literature on the factors that affect adoption of CF in Zambia in the following ways. First, the adopters and non-adopters of CF are matched based on the distribution of their similar characteristics for more robust results. Second, a parametric logistic regression model is used on the matched observations to identify the factors that affect adoption of CF in Zambia.

\section{Methodology}

\subsection{Data and Data Sources}

This study used data from a nationally representative survey of households in Zambia conducted in 2008 by the Central Statistical Office (CSO) with financial and technical support from the Food Security Research Project (FSRP) and the Ministry of Agriculture and Co-operatives (MACO). The data were collected as part of the Rural Incomes and Livelihood Survey and was the third Supplemental Survey to the 1999/2000 Post Harvest Survey (PHS) which was conducted in August/September 2000. One of the objectives of the Rural Incomes and Livelihood Survey was to study options to improve crop production, marketing and food consumption among smallholder farm households. Part of the data collected in the survey relevant for this study was about farmer adoption of CF practices and general perceptions. A total sample of 7,825 smallholder farm households was selected using a stratified three-stage sampling procedure. A large sample size was favored to increase statistical power especially for the semi-parametric propensity score matching (PSM) method that yields more efficient results when the sample size is large (Shadish, Cook \& Campbell, 2002).

\subsection{Types of Data}

Several factors as discussed in literature above have been documented as affecting smallholder farm households' decision to adopt CF or not to (Gebermedhin \& Swinton, 2001; Tembo \& Haggblade, 2003; Chomba, 2004; Kabwe \& Donovan, 2005; Rocstrom et al., 2006; Chiputwa et al, 2011; Nkegbe et al., 2011; Nyanga et al., 2011; Kassie et al., 2012; Nyanga, 2012). In this study, an adopter of CF was considered as the household that practiced at least any of the three main practices of $\mathrm{CF}$ which include minimum tillage, residue retention and leguminous crop rotations (Haggblade \& Tembo, 2003; FAO, 2006; Hobbs, 2007; CFU, 2007; Simpson \& 
Weamert, 2007). The choice of the variables that were hypothesized to affect adoption decisions of CF was based on the regularity with which a variable was cited in the literature. Using this benchmark, the variables described below and summarized in Table 1 were included in the logistic model.

\subsubsection{Farmer and Household Characteristics}

Most literature on agriculture technology adoption consider that the decision to adopt technologies including CF is affected by the characteristics of the farm household head and the household at large (Gebermedhin \& Swinton, 2001; Haggblade \& Tembo, 2003; Chomba, 2004; Kabwe \& Donovan, 2005; Rockström et al., 2009; Chiputwa et al., 2011; Nkegbe et al., 2011; Nyanga et al., 2011; Kassie et al., 2012; Nyanga, 2012). For instance, households that are large in their size are more likely to adopt CF because CF is documented to be labour intensive (Clay \& Reardon, 1994; Haggblade \& Tembo, 2003; Marenya \& Barett, 2007; Kassie et al., 2012). As the household size continues to increase, the likelihood of adoption of CF is expected to be high. Household heads are the final decision makers who may decide on adoption of new technologies at a farm. The age of the household head is likely to influence adoption of CF. Older farmers may not be enthusiastic to adopt new farming technologies such as $\mathrm{CF}$ as compared to younger farmers who are expected to be more willing to try new technologies (Jera \& Ajayi, 2008).

Other farmer and household characteristics such as gender, marital status and level of education are also expected to affect the decision to adopt CF as shown in Table 1. For example, female headed households may respond less favourably to adoption of new technology than male headed households due to wealth differences as well as cultural factors (Jera \& Ajayi, 2008; Kassie et al., 2012). For instance, males are usually in a better position to attend extension meetings in traditional set-ups and thus have more access to information on new agricultural technologies. However, some female heads are also enthusiastic enough and would as well be more willing to try now technologies such as CF (Jera \& Ajayi, 2008). Thus, we expect gender of the household head to have an ambiguous effect on adoption of CF. This also applies to the level of education of the household head. Some educated households would be conservative to adopt CF while others would be more willing to adopt it. Availability of off-farm income or income received by the household as in-kind may also affect the decision to adopt agricultural technologies such as CF (Tadesse \& Belay, 2004; Marenya \& Barett, 2007). For example, the household would be expected to use off farm income to purchase implements required for minimum tillage or planting in basins. However, it is also expected that income received as in-kind may be less likely be used to purchase such implements as they would not be a priority for such farm households, it would rather be used on purchasing basic items for the household. Therefore, it is not surprising that these factors are expected to have ambiguous effects on adoption of CF.

Household's labour availability is expected to positively affect the farm household's decision to adopt CF. CF is claimed to be labour intensive and therefore, smallholder farm households with sufficient labour are expected to be in a better position to adopt CF practices (Haggblade \& Tembo, 2003; Wall, 2007; Nyanga et al., 2011). Other factors such as ownership of assets such as mobile phones and radios are expected to enhance adoption of CF. Mobile phones would ease communication between smallholder farmers and extension workers and thus one would more easily obtain more advice on CF practices. Radios are sources of new information especially that agricultural programs are usually aired by interested Governments and NGOs. Households with more livestock and land holdings are expected to adopt $\mathrm{CF}$ as well. Livestock are a source of draught power that would be required for adoption of CF.

Furthermore, households with more land holdings would be more likely to allocate part of their farms to try new agricultural technologies such as CF (Tadesse \& Belay, 2004; Marenya \& Barett, 2007). Farm households with more secure land tenure are expected to be more likely to adopt CF than those that are not (Arellanes \& Lee, 2003; Gebremedhin \& Swinton, 2003; Haggblade \& Tembo, 2003; Tenge et al. 2004; Kassie et al., 2012). This is because the former would be able to use the land in any way they would want. For example, they would be more flexible to apply new technologies on it than those whose land tenure is insecure. Therefore, land tenure security is expected to have a positive effect on adoption of CF. 
Table 1. Description of variables used in the logistic model

\begin{tabular}{lll}
\hline Variable name & Variable Description & $\begin{array}{c}\text { Expected effect on } \\
\text { adoption of CF }\end{array}$ \\
\hline Dependent variable &
\end{tabular}

Adoption of $\mathrm{CF}$

Dummy $=1$ if household adopted CF, 0 otherwise

\section{Explanatory variables}

\section{Farmer and farm household characteristics}

Household size

Education level of household head

$$
\begin{aligned}
& \text { Primary education } \\
& \text { Basic education dummy } \\
& \text { Secondary education dummy } \\
& \text { Tertiary education dummy }
\end{aligned}
$$

Age of household in years

Marital status of head

Sex of household head

Labour availability.

In kind income

Off-farm income

Local variety

Total land holdings

Own a mobile phone

Own a radio

Livestock holding

Land tenure

\section{Climatic factors}

AER I

AER II

AER III
Household size

Primary education dummy (attended $=1,0$ otherwise)

Basic education dummy(attended $=1,0$ otherwise)

Secondary education (attended $=1,0$ otherwise)

Tertiary education (attended $=1,0$ otherwise)

Age of household head (years)

Marital status of household head ( $=1$ if single, $0 \mathrm{o} / \mathrm{w}$ )

Sex (=1 if male, 0 otherwise)

Labour availability in adult equivalents

Log of in kind income

Log of off-farm household income

If household used local varieties of crops ( $=1$ if yes)

Total amount of land owned by the household (ha)

Own a mobile phone ( $=1$ if yes, 0 otherwise)

Own a radio ( $=1$ if yes, 0 otherwise)

Livestock holding (Total Livestock Units)

Land tenure(if secure $=1,0$ otherwise)

Agro-ecological region 1 (yes $=1,0$ otherwise)

Agro-ecological region II (yes=1, 0 otherwise)

Agro-ecological region III (yes $=1,0$ otherwise)

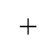

$+/-$

$+$

$+$

$+$

+/-

$+1$

$+/-$

$+$

+/-

$+/-$

$-/+$

$+$

$+$

$+$

$+1-$

$+$

$+$

$+$

-
+-
+
+
+
+
$+1-$
+
$+1-$
+
$+1-$
$+1-$
+
+
+
+

Access to price information (=1 if yes)

Belong to farmer group (yes $=1,0$ otherwise)

Access to loans ( $=1$ if yes, 0 otherwise)

Access to extension services, $1=y e s$

Distance to vehicular transport $(\mathrm{km})$

Distance to input market $(\mathrm{km})$

Distance to product market $(\mathrm{km})$

Access to price information,

Farmer group Membership

Access to loans

Access to extension services,

Distance to vehicular road

Distance to input market

Distance to product market

+
+
+
+
+
+
+
+
+
+
+
+
+
+
+
+
+
+
+

+
+
+
+-
+
-
$+/-$
$+/-$

\subsubsection{Climatic Factors}

Climatic factors would also affect the farm household's decision to adopt CF practices. Existing literature shows evidence that CF is more likely to be practiced in lower rainfall or drought prone areas (Clay et al., 2002; Haggblade \& Tembo, 2003; Gebremedhin \& Swinton, 2003). The reason for this is that CF practices help to conserve water in soils in such areas. Zambia's AER I and II receive less rain as compared to AER III. AER I and II sometimes experience dry spells and droughts and CF practices have thus been mainly been promoted in AER 
I and II areas as a way of conserving water for crop production (CFU, 2007). Therefore, farm households in AER I and II are expected to be more likely to adopt CF practices than those in AER III which is a high rainfall area and water conservation is not a major constraint.

\subsubsection{Market Access and Institutional Factors}

Other factors such as market access and institutional factors also affect adoption of CF. For example, it is expected that farm households that have limited or no access to loans have less capital available to purchase farm implements required for adoption of some CF practices. In addition, smallholder farm households need to have access to information about new agricultural technologies before they decide to adopt (Jera \& Ajayi, 2008). Such valuable information can be accessed through various forms of extension services such as public, private, NGOs, and other means. It is also through such means that smallholder farmers receive information related to input and output prices. Farm households that have such access are expected to be more likely to adopt CF than their counterparts who do not have access.

Furthermore, farm households with at least any of their members who belong to a farmer group are expected to be more likely to adopt CF as farmer groups are expected to be sources of vital farming information (Kassie et al. 2009; Wollni et al. 2010). Other factors such as distance to input market and access to vehicular roads are expected to influence the likelihood of adoption of CF by farm households. For instance, households in remote rural areas are less likely to adopt CF because of limited access to inputs or equipment such as rippers from agro-dealers. Table 1 gives a summary description of the variables and the a priori expectations.

\subsection{Data Analysis}

\subsubsection{Propensity Score Matching (PSM)}

In order to obtain observations of adopters and non-adopters of CF with statistically similar observable characteristics, PSM was used. The PSM framework is a semi-parametric approach that involves constructing a statistical comparison group by modeling the probability of participation on the basis of observed characteristics that are unaffected by the program (Rubin \& Rosenbaum, 1983). The framework makes work easier than it would be to match observations manually based on their visible characteristics. PSM rather matches observations of adopters and non-adopters of a program according to the predicted probability of adopting a superior technology (Rosebaum \& Rubin 1983; Heckman et al., 1998; Smith \& Todd, 2005). The propensity score is defined as the conditional probability of receiving the treatment given the pre-treatment variables (Rosenbaum and Rubin, 1983). Let $D_{i}$ denote a dummy variable equal to 1 if household $i$ adopts CF and 0 otherwise. The propensity score can be defined as;

$$
P(X)=\operatorname{Pr}\left(D_{i}=1 \mid X\right)=E\left(D_{i} \mid X\right)
$$

where $\boldsymbol{X}$ is a vector of the covariates that are postulated to affect adoption of CF (Rosenbaum and Rubin, 1983) and $E($.$) is the expectations operator.$

\subsubsection{Logit Model}

Decisions by farmers to adopt technologies are influenced by many factors. They range from farm household, climatic, market access and institutional factors. Modelling a relationship between the decision to adopt and not to adopt a technology with the observed factors requires use of qualitative response models. Commonly used models of this type are probit and logit models. Both the logit and probit models yield similar parameter estimates and it is difficult to distinguish them statistically (Aldrich \& Nelson, 1990). However, the logistic and cumulative normal functions are very close in the mid-range, but the logistic function has slightly heavier tails than the cumulative normal function (Maddala, 1983). This implies that the normal curve approaches the axes more quickly than the logistic curve. Therefore, the logit model was used in this study since it is easier and simpler to interpret and thus has been widely applied in adoption studies (for example; Bagi, 1983; Polson \& Spencer, 1991; Adesina \& Sirajo, 1995). The adoption decision by farmers is specified as;

$Y=f(X, e)$ where $e$ is the stochastic disturbance term assumed to follow a logistic distribution (Amemiya, 1985).

The logit model is generally specified as follows (Amemiya, 1985; Cameron \& Trivedi, 2005);

$$
\operatorname{Pr}\left(D_{i}=1 \mid X\right)=\Lambda\left(x^{\prime} \beta\right)=\frac{e^{X^{\prime} \beta}}{1+e^{X^{\prime} \beta}}
$$


Where $\boldsymbol{\beta}$ is a vector of parameters to be estimated, $\boldsymbol{X}$ is as defined in equation (1) and $\Lambda($.$) is a logistic$ cumulative distribution function (CDF). The logit model is estimated by maximum likelihood (ML), assuming independence across observations and that the ML estimator of $\boldsymbol{\beta}$ is consistent and asymptotically normally distributed. However, the estimation rests on the strong assumption that the latent error term is normally distributed and homoscedastic. Data management and analysis were done in STATA.

\section{Results and Discussions}

\subsection{Descriptive Statistics}

Table 2 presents descriptive statistics for the variables used in this study. There are three major columns showing a description of the total sample, adopters of CF and non-adopters. Within these columns are the variable means and their standard deviations for the total sample, $\mathrm{CF}$ adopters and non-adopters. Matched observations were based on the calculated propensity scores. PSM results showed that 2,437 smallholder farm households adopted CF while 4,951 smallholder farm households were non-adopters representing a 33 percent adoption rate. The decision to adopt $\mathrm{CF}$ was the main dependent variable and was equal to 1 if a smallholder farm household adopted $\mathrm{CF}$, zero otherwise. The explanatory variables were farmer and household characteristics, climatic factors, and market access and institutional factors.

The average household size for the total sample and for both CF adopters and non-adopters was about 6 members. The average age of the household head for the total sample was 49 years while for CF adopters, it was 51 years. For the non-adopters, the household head's average age was about 48 years. From Table 1, only about 6 percent of the CF smallholder farm households were headed by single persons. However, about 41 percent of the smallholder farm households that did not adopt CF were headed by single persons by marital status. About 77 percent of the smallholder farm households, both CF adopters and non-adopters were male headed.

Level of education of the household head was categorized into four levels; primary, basic, secondary and tertiary education. An average of 78 percent of farm households that adopted CF had acquired primary education while 74 percent of the non-adopters had acquired primary education. The level of education for both groups was low. For example, only an average of 2 percent of smallholder farm households that adopted CF had acquired tertiary education while only an average 3 percent of the CF non adopters had acquired tertiary education.

Location of a household in an AER is one of the factors identified by past literature as being significant in adoption of CF (Nyanga et al., 2011; CFU, 2007). In this study, it was found that 28 percent of CF adopters were located in AER I while 19 percent of non-adopters were located in AER I. Among the adopters, 33 percent were located in AER II while 22 percent of the non-adopters were located in agro-ecological region II. Within the total sample, 12.4 percent of the households were located in AER III. 
Table 2. Descriptive statistics

\begin{tabular}{|c|c|c|c|c|c|c|}
\hline \multirow[b]{2}{*}{ Variable Name } & \multicolumn{2}{|c|}{ Total sample } & \multicolumn{2}{|c|}{ CF adopters } & \multicolumn{2}{|c|}{ CF non-adopters } \\
\hline & Mean & Std. Dev. & Mean & Std. Dev. & Mean & Std. Dev. \\
\hline \multicolumn{7}{|l|}{ Dependent variables } \\
\hline $\mathrm{CF}$ adoption ( $=1$ if yes) & 0.330 & 0.470 & 1.000 & 0.000 & 0.000 & 0.000 \\
\hline \multicolumn{7}{|l|}{ Independent variables } \\
\hline \multicolumn{7}{|c|}{ Farmer and household characteristics } \\
\hline Household size & 6.015 & 2.986 & 6.195 & 3.052 & 5.927 & 2.949 \\
\hline Primary education & 0.753 & 0.431 & 0.780 & 0.415 & 0.740 & 0.438 \\
\hline Basic education & 0.247 & 0.431 & 0.237 & 0.425 & 0.252 & 0.434 \\
\hline Secondary education & 0.079 & 0.270 & 0.076 & 0.264 & 0.081 & 0.273 \\
\hline Tertiary education & 0.027 & 0.161 & 0.018 & 0.132 & 0.031 & 0.173 \\
\hline Age of head (yrs.) & 49.072 & 15.246 & 51.324 & 14.699 & 47.964 & 15.389 \\
\hline Marital status(=1 if single) & 0.293 & 0.455 & 0.061 & 0.239 & 0.408 & 0.491 \\
\hline Sex of head(=1 if male) & 0.776 & 0.417 & 0.772 & 0.420 & 0.778 & 0.416 \\
\hline Labour availability & 5.016 & 2.522 & 5.220 & 2.575 & 4.916 & 2.490 \\
\hline Log of in kind income & 14.731 & 1.264 & 14.769 & 1.216 & 14.712 & 1.287 \\
\hline Log of off farm income & 5.158 & 5.697 & 2.161 & 2.682 & 2.161 & 2.705 \\
\hline Total land holding (ha) & 1.929 & 2.350 & 1.971 & 2.593 & 1.909 & 2.222 \\
\hline Own a radio (=1 if yes) & 0.601 & 0.490 & 0.616 & 0.487 & 0.594 & 0.491 \\
\hline Own mobile phone & 0.240 & 0.427 & 0.240 & 0.427 & 0.239 & 0.427 \\
\hline Livestock holding & 3.508 & 10.500 & 3.839 & 9.388 & 3.345 & 10.992 \\
\hline Land tenure & 0.031 & 0.173 & 0.028 & 0.165 & 0.033 & 0.177 \\
\hline \multicolumn{7}{|l|}{ Climatic factors } \\
\hline Agro ecological region I & 0.219 & 0.413 & 0.281 & 0.449 & 0.188 & 0.391 \\
\hline Agro ecological region II & 0.255 & 0.436 & 0.326 & 0.469 & 0.220 & 0.414 \\
\hline Agro ecological region III & 0.124 & 0.330 & 0.119 & 0.323 & 0.127 & 0.333 \\
\hline \multicolumn{7}{|c|}{ Market Access \& Institutional factors } \\
\hline Access to price information & 0.770 & 0.421 & 0.792 & 0.406 & 0.759 & 0.428 \\
\hline Extension ( $=1$ if yes) & 0.164 & 0.371 & 0.187 & 0.390 & 0.153 & 0.360 \\
\hline Farmer group ( $=1$ if yes) & 0.193 & 0.245 & 0.192 & 0.258 & 0.1940 & 0.238 \\
\hline Access to loan (=1 if yes) & 0.106 & 0.300 & 0.183 & 0.387 & 0.067 & 0.251 \\
\hline Extension service ( $=1$ if yes) & 0.106 & 0.300 & 0.183 & 0.387 & 0.067 & 0.251 \\
\hline Dist. to vehicular road $(\mathrm{km})$ & 8.990 & 17.200 & 7.480 & 14.171 & 9.739 & 18.604 \\
\hline Dist. to input market $(\mathrm{km})$ & 38.684 & 39.500 & 36.963 & 37.565 & 39.532 & 40.337 \\
\hline Dist. to prod market $(\mathrm{km})$ & 24.482 & 34.400 & 21.512 & 31.674 & 25.944 & 35.572 \\
\hline Sample size & & 7,388 & & 2,437 & & 4,951 \\
\hline
\end{tabular}

In terms of the assets owned, about 62 percent of the smallholder farm households that practiced CF owned a radio while only about 59 percent of non-adopters owned this asset. A radio is useful for farmers. For example, they would be able to listen to agricultural programs some of which may include promotion of agricultural technologies. Moreover, about 24 percent of the both CF adopters and non-adopters owned mobile phones. These in one way or another can ease communication between smallholder farmers and agricultural extension workers. Among market access and institutional factors, access to price information and extension services were also discussed. The mean values for these variables are similar meaning that these two groups of smallholder 
farm households were similar. Results show that about 77 percent of the households in the total sample had access to information about input and output prices while 79 percent of $\mathrm{CF}$ adopters and about 76 percent of the non-adopters had such an opportunity (Table 2). Furthermore, about 18 percent of the CF adopters and about 7 percent of the non-adopters had access to loans. Other variables included in the category of market access and institutional factors were distance to the input and product markets, distance to a vehicular road. The average distances to input markets for the smallholder farmers in the total sample, CF adopters and non-adopters were 38, 36 and 39 kilometres, respectively. Average distances to output markets for the CF adopters, non-adopters and for all households in the total sample were lower than distances to input markets.

\subsection{Empirical Results}

The region of common support from the PSM model was captured and 7,388 observations fell within it. Those that did not satisfy the common support condition were dropped in order to have a comparable sample. The null hypothesis supporting joint significance of the covariates in the PSM model was rejected $(p<0.00)$. The balancing test was satisfied to indicate that within the common support, the CF comparison and treatment smallholder farm households had similar observable characteristics. Variables that were selected into the PSM model were at least correlated with the treatment variable. This was to minimize bias in the selection of variables into the PSM model (Brookhart et al., 2006).

\subsubsection{Logistic Regression Results}

The logistic regression model results are shown in Table 3. Model diagnostics were performed to check for possible model specification errors. The model was statistically significant at 1 percent significance level. Tests showed that the model was free from omitted variables and multicollinearity. For the goodness of fit, the Hosmer-Lemeshow test was statistically significant confirming that the model fitted well $(\mathrm{HL}=7224.91)$ and 72.47 percent of the values were correctly classified, the rest were misclassified. 
Table 1. Logistic regression results

\begin{tabular}{|c|c|c|c|}
\hline Variable name & Coefficient & Odds ratio & Robust Standard errors \\
\hline & $(1)$ & $(2)$ & (3) \\
\hline \multicolumn{4}{|l|}{ Farmer and household characteristics } \\
\hline Household size & -0.226 & $0.797 * * *$ & 0.056 \\
\hline Household size squared & 0.005 & $0.995^{* *}$ & 0.002 \\
\hline \multicolumn{4}{|l|}{ Education level of household head } \\
\hline Primary education, $1=$ yes & -0.020 & 0.980 & 0.124 \\
\hline Basic education, $1=$ yes & 0.019 & 1.019 & 0.086 \\
\hline Secondary education, $1=$ yes & 0.050 & 1.052 & 0.186 \\
\hline Tertiary education, $1=$ yes & -0.071 & 0.931 & 0.452 \\
\hline Age of household head (years) & 0.091 & $1.095 * * *$ & 0.014 \\
\hline Age of household head squared & -0.001 & $0.999 * * *$ & 0.001 \\
\hline Marital status, $1=$ single & -2.645 & $0.071^{* * *}$ & 0.007 \\
\hline Sex of head, $1=$ male & -0.062 & 0.940 & 0.073 \\
\hline Labour availability in adult equivalents & 0.423 & $1.527 * * *$ & 0.117 \\
\hline Farmer group (belong=1, 0 otherwise) & -0.124 & 0.883 & 0.106 \\
\hline Log of off-farm income & -0.029 & $0.971 * *$ & 0.014 \\
\hline Log of in kind income & 0.039 & $1.04 * *$ & 0.033 \\
\hline If used local varieties of crops, $1=$ yes & -0.121 & 0.886 & 0.075 \\
\hline Total land holding (hectares) & -0.014 & 0.986 & 0.016 \\
\hline Land tenure, $1=$ secure & -0.167 & 0.846 & 0.144 \\
\hline Own a mobile phone, $1=$ yes & -0.001 & 0.999 & 0.081 \\
\hline Own a radio, $1=$ yes & 0.037 & 1.038 & 0.068 \\
\hline Livestock holding (TLU) & -0.011 & $0.989 * * *$ & 0.004 \\
\hline \multicolumn{4}{|l|}{ Climatic factors } \\
\hline AER I, 1=yes & $0.920 * * *$ & $2.522 * * *$ & 0.202 \\
\hline AER II, $1=$ yes & $0.660 * * *$ & $1.939 * * *$ & 0.155 \\
\hline AER III, $1=$ yes & -1.382 & 0.251 & 0.320 \\
\hline \multicolumn{4}{|l|}{ Market access and institutional factors } \\
\hline Access to price information, $1=$ yes & 0.118 & 1.126 & 0.113 \\
\hline Access to extension services, $1=y e s$ & -0.035 & 0.965 & 0.079 \\
\hline Distance to vehicular road $(\mathrm{km})$ & -0.004 & $0.996^{* *}$ & 0.002 \\
\hline Distance to input market (km) & 0.001 & 1.001 & 0.001 \\
\hline Distance to product market $(\mathrm{km})$ & -0.001 & 0.999 & 0.001 \\
\hline Access to loans, $1=$ yes & 1.028 & $2.796 * * *$ & 0.313 \\
\hline Constant & -4.342 & $0.013 * * *$ & 0.010 \\
\hline Observations & & & 7,388 \\
\hline
\end{tabular}

***Significant at 1 percent; **Significant at the 5 percent level *Significant at the 10 percent level;

Results show that household size is statistically significant at affecting adoption of CF. An increase in household size is associated with a reduction in the odds of adoption of CF when other factors are held constant. But many household members would add more labour required for $\mathrm{CF}$ activities. However, it is not the number of people joining the farm household but also if those additional members will be in a position to help in the adoption of 
CF collectively. In addition, results indicate that increase in household size is associated with marginal decrease in the odds of adopting CF, when other factors are held constant. This implies that there is no linear relationship between household size and the likelihood of adoption of CF.

Age of the household head is statistically significant at affecting adoption of CF, ceteris paribus. The positive sign of the coefficient of age of the household head implies that age of the household head increases the odds of adopting CF. This might be because older household heads are often associated with long years of experience in farming (Jera \& Ajayi, 2008). Thus, they would more likely and positively affect CF adoption decisions. However, the negative sign of the coefficient of the variable age squared of the household head implies there is a time in life of the household head, when age would no longer positively affect adoption of agricultural technologies but negatively, the relationship that relates to the life cycle hypothesis in economic theory. Marital status of the household head is also statistically significant at affecting adoption of CF. Single headed households are less likely to adopt CF than farm households whose heads are married, holding other factors constant. A plausible explanation could be that married farmers have higher social connections and interactions with other farm households which gives them better access to information about agricultural technologies.

Labour availability at a farm household is also statistically significant at affecting adoption of CF. Availability of labour in a household is associated with an increase in the odds of adopting CF, ceteris paribus. Results indicate that smallholder farm households that have more labour available for agricultural use would more likely adopt $\mathrm{CF}$ in Zambia. This result is consistent with other studies on CF whose findings show that $\mathrm{CF}$ is labour intensive and requires that adopters have enough labour (Haggblade \& Tembo, 2003; Wall, 2007; Nyanga et al., 2011).

Availability of off-farm income is statistically significant at affecting adoption of CF in Zambia. Results indicate off-farm incomes reduce the odds of adopting CF among smallholder farmers, holding other things constant. A more plausible explanation would be that households' major sources of income are off-farm activities and that they would less likely invest in agricultural technologies. This result is consistent with those by Marenya and Barrett (2007) in Kenya. One other explanation would be that non-agricultural incomes in Zambia may not necessarily be used by smallholder farmers to meet capital costs required to implement new agricultural technologies but rather to acquire other basic needs in their households. Nonetheless, the positive and statistically significant sign on income received as in-kind implies that farm households that receive income as in-kind are more likely to adopt CF.

The variable livestock holding is statistically significant affecting adoption of CF. Results indicate that smallholder farm households that have livestock are generally less likely to adopt CF in Zambia. The reason may be that livestock are devoted to provide labour for conventional practices such as ploughing. However, this finding however does not corroborate with results by a study by Kassie et al, (2012) in Tanzania. As expected, results indicate that AER in which the household is located significantly affects adoption of CF. Smallholder farm households located in Zambia's AER I or AER II are more likely to adopt CF. As mentioned before, AER I and II are low rainfall and drought prone areas in Zambia where CF is scientifically recommended (Haggblade \& Tembo, 2003; Nyanga et al, 2011). These results corroborate with past findings (for example, Ervin \& Ervin, 1982; Reardon \& Vosti, 1997a; Clay et al., 2002; Haggblade \& Tembo, 2003; Gebremedhin \& Swinton, 2003). AER III has a negative coefficient though it is not statistically significant at affecting adoption of CF.

Distance to a vehicular road is statistically significant at affecting adoption of CF in Zambia. An area is considered more remote, the longer the distance is to access roads that are passable by vehicles. Results indicate that farm households that are located in remote areas are less likely to adopt CF. This is not surprising because in such areas, access to extension services, field visits by agricultural staff and interactions with farmers is usually limited due to poor road infrastructure. Furthermore, smallholder farmers that have access to loans are more likely to adopt CF in Zambia. The coefficient of the variable access to loans is positive and statistically significant at affecting adoption of CF. This finding is consistent with Kassie et al. (2012). The likely reason is that in developing countries, where most markets are imperfect, interlinked contracts may provide credit, inputs, and information that enhances adoption of agricultural technologies (Gebermedhin \& Swinton, 2001). The coefficient of the variable access to extension was negative though not statistically significant at affecting adoption of CF, a result that contradicts the results by Haggblade and Tembo (2003) but corroborates with Amsalu and de Graaf (2006). This confirms the finding that extension service is not both necessary and sufficient to affect adoption of technologies but also the quality of the extension service matters (Kassie et al., 2012).

Some of the other results in Table 3 are not in agreement with findings of some past research. For example, land tenure was not statistically significant at affecting adoption of CF while others have reported that it significantly affects adoption of soil conservation technologies (for example, Gebremedhin \& Swinton, 2003; Jansen et al. 
2006; Kassie et al. 2009; Nyangena, 2011). However, our result is consistent with other previous studies (Shiferaw \& Holden, 1998; Amsalu \& de Graaf, 2006).

\section{Conclusions and Recommendations}

Several farmer, household, climatic, market access and institutional characteristics were found to significantly affect adoption of CF by smallholder farm households in Zambia. The econometric analysis showed that household size; age of household head; marital status; labour availability; distance to access of vehicular roads; location in AER I, AER II; in-kind income and off-farm income significantly affect adoption of CF. Household size was found to negatively affect adoption of CF but was observed to have a positive marginal increase on the likelihood for farm households to adopt as the household increases in size. Age of the household head had a positive but negative marginal effect on the decision to adopt CF. Smallholder farmers in their youthful stage of lives would be versatile to adopting new technologies but it reaches a point in life when they would desist from adopting new technologies. Married household heads were more likely to affect adoption of CF than single household heads. Labour availability in the farm household was found to positively affect adoption of the technology. This finding was not surprising as CF practices are documented to be more labour intensive.

Similarly, farm households located in either AER I or AER II were more likely to adopt CF. As mentioned before, AER I and AER II are low rainfall and drought prone areas and it is not surprising that households located in these areas would resort to adoption of CF as an adaptation strategy to droughts and inadequate rainfall. Thus more extension efforts to promote CF should be directed in AER I and II where adoption is significant. AER III might be useful for experimenting CF practices so as to check whether they would prove satisfactory results if practiced using recommended methods.

Farm households that had off-farm income were found to be less likely to adopt CF. This might be because off-farm activities would divert the time from being allocated to agricultural investments and result into the farm household to less likely adopt CF technologies. However, farm households whose income was received as in-kind were found to be more likely to adopt CF. This finding might mean that income received as in-kind was readily available for acquiring implements required for $\mathrm{CF}$ practices such as rippers and any other. This is not surprising as some $\mathrm{CF}$ practices such as ripping, basins would still require use of farm implements. Furthermore, farm households that were able to acquire loans were more likely to adopt CF. Funds acquired from loans would be useful to finance agricultural needs, for example, they could be used to purchase farm implements and also acquire labour in labour deficient periods. Based on this finding, it is recommended that availing some forms of affordable credit to enable smallholder farmers to acquire necessary inputs can assist in the promotion or adoption of CF practices.

Access to roads passable by vehicles was found to significantly affect adoption of CF. Farm households in the remote areas lack access to basic needs and infrastructure such as roads. Therefore, it is not a surprise that farm households in more remote areas would be less likely to adopt CF. For example, they would less likely benefit from field visits, demonstrations by extensionists and other services that would be accessed where the road network is sound. One recommendation to solve this problem is the need for the government to improve the road infrastructure in Zambia's remote areas so that promotion of CF would be one of the positive externalities that would come with improvements in the roads. Improved roads and accessibility would also lead to agricultural extension services being provided to smallholder farm households that are in remote areas and thus enhance adoption of CF.

\section{Acknowledgements}

The authors gratefully appreciate the contributions made by Indaba Agricultural Policy Research Institute (IAPRI) and Michigan State University (MSU) through funding and release of their databases. Without their support, this paper would not have be completed.

\section{References}

Aldrich, J. H., \& Nelson, F. D. (1990). Linear Probability, Logit and Probit Models. Sage Publications, London.

Amemiya, T. (1985). Advanced Econometrics. Cambridge: Harvard University Press.

Amsalu, A., \& de Graaf, J. (2006). Determinants of adoption and continued use of stone terraces for soil and water conservation in an Ethiopian highland watershed. Ecological Economics, (61) 294-302.

Arellanes, P., \& Lee, D. R. (2003). The Determinants of Adoption of Sustainable Agriculture Technologies. Paper presented at the 25th Conference of International Association of Agricultural Economists, Durban, South Africa. Retrieved from http://ecsocman.hse.ru/data/120/661/1219/050.pdf 
Arslan, A., McCarthy, N., Lipper, L., Asfaw, S., \& Cattaneo, A., (2013). Adoption and Intensity of Adoption of Conservation Farming Practices in Zambia. Working Paper 71. Published jointly with the Agricultural Development Economics Division (ESA) of the Food and Agriculture Organization of the UN. Retrieved from http://www.aec.msu.edu/agecon/fs2/zambia/index.htm

Bagi, F. S. (1983). A Logit model of farmers' adoption decisions about credit. Southern Journal of Agricultural Economics, (15), 13-19.

Cameron, C. A., \& Trivedi. P. K. (2005). Microeconometrics: Methods and Applications. Cambridge: Cambridge University Press. http://dx.doi.org/10.1017/CBO9780511811241

Chiputwa, B., Langyintuo, A. S., \& Wall, P. (2011). Adoption of conservation agriculture technologies by smallholder farmers in the Shamva District of Zimbabwe: A Tobit application. Paper accepted for the 2011 meeting of the Southern Agricultural Economics Association (SAEA) in Texas, USA, Feb 5-8, 2011. Retrieved from http://ageconsearch.umn.edu/bitstream/98851/2/Chiputwa_etal_SAEA_Paper.pdf

Chomba, G. (2004). Factors affecting smallholder farmers' adoption of soil and water conservation practices in Zambia. M.Sc. thesis. Michigan State University. Retrieved from http://fsg.afre.msu.edu/zambia/chomba_thesis_updated_version.pdf

Clay, D. C., \& Reardon. T. (1994). Determinants of farm level conservation investments in Rwanda. International Association of Agricultural Economists Working paper No. 7. Harare, Zimbabwe.

Clay, D. C., Kelly, V., Mpyisi, E., \& Reardon, T. (2002). Input Use and Soil Conservation Investments among Farm Households in Rwanda: Patterns and Determinants. In C. B. Barret, F. Place, \& A. A. Aboud (Eds.), Natural Resources Management in African Agriculture. New York, NY, CABI International.

Conservation Farming Unit. (2005). Annual Report. ZNFU, Lusaka.

Conservation Farming Unit. (2007). Conservation farming handbook for small holders in Regions I and II. Lusaka: ZNFU

Derpsch, R. (2003). Conservation tillage, no-tillage and related technologies. Conservation Agriculture Environment Farmer Experience Innovation. Socio-Economic Policy, 181-190.

Ervin, C. A., \& Ervin, D. E. (1982). Factors affecting the use of soil Conservation practices: Hypothesis, evidence and policy implications. Land Economics, 58(3), 277-292. http://dx.doi.org/10.2307/3145937

Fowler, R., \& Rockstrom, J. (2001). Conservation tillage for sustainable agriculture- an agrarian revolution gathers momentum in Africa. Soil Till. Res. 61, 93-108. http://dx.doi.org/10.1016/S0167-1987(01)00181-7

Gavian, S., \& Fafchamps, M. (1996). Land tenure and allocative efficiency in Niger. American Journal of Agricultural Economics, 78, 460-471. http://dx.doi.org/10.2307/1243717

Gebermedhin, B., \& Swinton, S. M. (2001). Investment in soil conservation in northern Ethiopia: the role of land tenure security and public programs. Agricultural Economics, 29, 69-84. http://dx.doi.org/10.1111/j.1574-0862.2003.tb00148.x

Giller, K. E., Witter, E., Corbeels, M., \& Tittonell, P. (2009). Conservation agriculture and smallholder farming in Africa: The heretics' view. Field Crops Research, 114(1), 23-34. http://dx.doi.org/10.1016/j.fcr.2009.06.017

Haggblade, S., \& Tembo, G. (2003). "Early Evidence on Conservation Farming in Zambia." Paper presented at the Conference: "Reconciling Rural Poverty and Resource Conservation: Identifying Relationships and Remedies" held at Cornell University, May 2-3, 2003. Ithaca, N.Y.: Cornell University.

Hayes, J., Roth, M., \& Zepeda, L. (1997). Tenure security, investment and productivity in Gambian agriculture: a generalised probit analysis. American Journal of Agricultural Economics, 79, 369-382. http://dx.doi.org/10.2307/1244136

Heckman, J., Ichimura, H., \& Todd, P. (1998). Matching as an Econometric Evaluation Estimator. Review of Economic Studies, 65, 261-294. http://dx.doi.org/10.1111/1467-937X.00044

Hobbs, P. R. (2007). Conservation agriculture: what is it and why is it important for future Sustainable food production? Journal of Agricultural Science, 145, 127-137. http://dx.doi.org/10.1017/S0021859607006892

Holden, S. T., Akinwoum, M., \& Shiferaw, B. (2001). "Land Degradation, Drought and Food Security: A Bioeconomic Model with Market Imperfections." Paper presented at the National Workshop on Policies for Sustainable Land Management in Addis Ababa, Ethiopia.

Jera, R., \& Ajayi, O. C. (2008). Logistic modelling of smallholder livestock farmers' adoption of tree-based 
fodder technology in Zimbabwe. Agrekon, 47(3), 379-392. http://dx.doi.org/10.1080/03031853.2008.9523806

Kabwe, S., \& Donovan, C. (2005). Sustained use of Conservation Farming practices among small scale farmers in Zambia. Michigan State University, USA.

Kassie, M., \& Holden, S. (2006). Parametric and Non-parametric Estimation of Soil Conservation Impact on Crop Productivity in the Ethiopian Highlands. International Association of Agricultural Economists, Brisbane, Australia.

Kassie, M., Jaleta, M., Shiferaw, B., Mmbando, F., \& Muricho, G. (2012). Plot and Household-Level Determinants of Sustainable Agricultural Practices in Rural Tanzania. Environment for Development. Discussion paper series. Retrieved from http://www.rff.org/RFF/Documents/EfD-DP-12-02.pdf

Kassie, M., Pender, J., Yesuf, M., Kohlin, G., Bluffstone, R., \& Mulugeta, E. (2008). Estimating Returns to Soil Conservation Adoption in the Northern Ethiopian Highlands. Agricultural Economics, 38, 213-232. http://dx.doi.org/10.1111/j.1574-0862.2008.00295.x

Keyser, J., \& Mwanza, M. H. (1996). Residue retention. The Institute of African Studies, University of Zambia.

Marenya, P. P., \& Barrett, C. B. (2007). Household-level determinants of adoption of Improved natural resources management practices among smallholder farmers in western Kenya. Food Policy, 32(4), 515-536. http://dx.doi.org/10.1016/j.foodpol.2006.10.002

Nkegbe, P. K., Shankar, B., \& Ceddia, G. M. (2011). Smallholder Adoption of Soil and Water Conservation Practices in Northern Ghana. In 2011 International Congress, August 30-September 2, 2011, Zurich, Switzerland (No. 114608). European Association of Agricultural Economists. Retrieved from http://ageconsearch.umn.edu/bitstream/114608/2/Nkegbe_Paul_347.pdf

Nyanga, P. H. (2012). Factors Influencing Adoption and Area under Conservation Agriculture: A Mixed Methods Approach. Sustainable Agriculture Research, 1(2).

Nyanga, P. H. (2012). Food Security, Conservation Agriculture and Pulses: Evidence from Smallholder Farmers in Zambia. Journal of Food Research, 1(2), 120-138. http://dx.doi.org/10.5539/jfr.v1n2p120

Nyanga, P. H., Johnsen, F. H., Aune, F. H., \& Kalinda, T. H. (2011). Smallholder Farmers' Perceptions of Climate Change and Conservation Agriculture: Evidence from Zambia. Journal of Sustainable Development, 4(4), 73-85. http://dx.doi.org/10.5539/jsd.v4n4p73

Nyangena, W., \& Köhlin, G. (2008). Estimating Returns to Soil and Water Conservation Investments. An Application to Crop Yield in Kenya. Environment for Development Discussion Paper Series. Economics for Development DP 08-32.

Pender, J., \& Gebremedhin, B. (2006). Land management, crop production and household income in the highlands of Tigray, northern Ethiopia: an econometric analysis. In J. Pender, F. Place, \& S. Ehui (Eds.), Strategies for Sustainable Land Management in the East African Highlands (pp. 107-140). Washington D.C.: International Food Policy Research Institute. Retrieved from http://www.ifpri.org/sites/default/files/publications/oc53.pdf\#page=125

Pender, J., \& Kerr, J. M. (1998). Determinants of farmer's indigenous soil and Water conservation investments in semi-arid India. Agricultural Economics, 19, 113-125. http://dx.doi.org/10.1016/S0169-5150(98)00026-7

Pieri. C., Evers, Landers, G., Connell, P., \& Terry, E. (2002). No-Till Farming for Sustainable Rural Development. Agriculture \& Rural Development Working Paper. Washington, DC 20433. Retrieved from http://www.betuco.be/CA/No-tillage\%20Farming\%20for\%20Sustainable\%20Development.pdf

Polson, R., \& Spencer, D. S. C. (1991). The technology adoption process in subsistence agriculture: the case of $\begin{array}{llllll}\text { cassava in southwestern Nigeria. Agricultural Systems, } & 36, & 65-77 .\end{array}$ http://dx.doi.org/10.1016/0308-521X(91)90108-M

Reardon, T., \& Vosti, S. A. (1995). Links Between Rural Poverty and the Environment in Developing Countries: Asset Categories and Investment Poverty. World Development, 23(9), 1495-1506. http://dx.doi.org/10.1016/0305-750X(95)00061-G

Rockström, J., Kaumbutho, P., Mwalley, J., Nzabi, A. W., Temesgen, M., Mawenya, L., Barron, J., Mutua, J., \& Damgaard-Larsen, S. (2009). Conservation farming strategies in East and Southern Africa: yields and rain water productivity from on-farm action research. Soil and Tillage Research, 103(1), 23-32. http://dx.doi.org/10.1016/j.still.2008.09.013 
Rosenbaum, P., \& Rubin, D. (1983). The Central Role of the Propensity Score in Observational Studies for Causal Effects. Biometrika, 70, 41-55. http://dx.doi.org/10.1093/biomet/70.1.41

Shadish, W., Campbell, T., \& Cook, D. (2002). Experimental and Quasi-experimental Designs for Generalized Causal Inference. Houghton and Mifflin, Boston. Retrieved from http://post.queensu.ca/ hh11/assets/applets/Causal_inference_in_experimental_and_quasi-experimental_de signs.pdf

Shiferaw, B., \& Holden, S. T. (1998). Resource degradation and adoption of land conservation technologies in the Ethiopian Highlands: A case study in Andit Tid, North Shewa. Agricultural Economics, 18(3), 233-247. http://dx.doi.org/10.1016/S0169-5150(98)00036-X

Simpson T. W., \& Weamert, S. E. (2007). Residue retention Practices Definition and Nutrient and Sediment Reduction Efficiencies. University of Maryland/Mid-Atlantic Water Program, Maryland.

Smith, J., \& Todd, P. (2005). Does matching overcome LaLonde's critique of Nonexperimental Estimators? Journal of Econometrics, 125(1-2), 305-353. http://dx.doi.org/10.1016/j.jeconom.2004.04.011

Tadesse, M., \& Belay, K. (2004). Factors Influencing Adoption of Soil Conservation Measures in Southern Ethiopia: The Case of Gununo Area. Journal of Agriculture and Rural Development in the Tropics and Subtropics, $\quad$ 105(1), 49-62. $\quad$ Retrieved from http://www.uni-sql.de/products/dokumente/jarts/vol_105_1_free.pdf

United Nations, Food and Agricultural Organization. (2006). Conservation agriculture website. Retrieved from http://www.fao.org/waicent/faoinfo/agricult/ags/AGSE/agsee/general/OBJETIVE.html

Wall, P. (2007). Tailoring conservation agriculture to the needs of small farmers in developing countries: An analysis of issues. Journal of Crop Improvement, 19, 137-155. http://dx.doi.org/10.1300/J411v19n01_07

\section{Notes}

Note 1. Zambia has three AER. AER I mainly covers the Southern part of the country and is characterized by rainfall patterns of between $400 \mathrm{~mm}$ to $800 \mathrm{~mm}$ per year. AER II covers the Central and Eastern of the country with rainfall patterns between 800 and $1000 \mathrm{~mm}$ per year. AER III covers the Northern parts of the country with rainfall above $1000 \mathrm{~mm}$ per year.

\section{Copyrights}

Copyright for this article is retained by the author(s), with first publication rights granted to the journal.

This is an open-access article distributed under the terms and conditions of the Creative Commons Attribution license (http://creativecommons.org/licenses/by/3.0/). 